\title{
Is Restorative Justice Conferencing Appropriate for Youth Offenders?
}

Masahiro Suzuki ${ }^{1}$; William R Wood ${ }^{1}$

${ }^{1}$ School of Criminology and Criminal Justice, Griffith University, Brisbane, Australia; Griffith Criminology Institute

\section{Corresponding Author}

Name: Masahiro Suzuki

Position: Doctoral candidate

Affiliation: School of Criminology and Criminal Justice, Griffith University, Brisbane, Australia; Griffith Criminology Institute

Tel: +61 (0)737351202

Email: masahiro.suzuki@griffithuni.edu.au

Published in Criminology \& Criminal Justice 2017 doi: 10.1177/1748895817722188. 


\begin{abstract}
While many studies on restorative justice conferencing (RJC) for youth offenders have shown favourable outcomes such as victim satisfaction and fairness, and offender accountability and perceived legitimacy, other studies have demonstrated more problematic outcomes in terms of mutual understanding, sincerity of apology and reoffending. Given the complexity of RJC as a concept and as a process, such 'limits' might be attributed to the capacity and characteristics of youth offenders. To date, however, there has been little examination of developmental, cognitive, or environmental impediments on the part of youth offenders in terms of achieving restorative outcomes in RJC. This paper discusses the potential impacts of limited developmental and cognitive capacities of youth offenders on the RJC process and outcomes.
\end{abstract}

\title{
Keywords
}

Restorative justice; young offender; maturity; developmental psychology; cognitive capacity 


\section{Introduction}

The growth and development of restorative justice conferencing (RJC) in the last three decades has occurred largely within youth justice (Zinsstag, 2012). There are several reasons for this including the perceived appropriateness of RJC for youth offending (Bruce et al., 2012; Richards, 2012), public tolerance for rehabilitative approaches for youth offenders (Bazemore and Walgrave, 1999; Richards, 2012), and the relative amenability of youth offenders for RJC (Bazemore and Walgrave, 1999; Bottoms, 2003). It is almost axiomatic today within RJC literature and practice that RJC is suitable and appropriate for youth offenders. Numerous evaluative studies of RJC have been conducted within the last thirty years. When compared to existing criminal justice approaches, many of these studies have demonstrated favourable outcomes for victims in terms of satisfaction, fairness and redress; and for offenders in terms of accountability and perceived legitimacy (Strang et al., 2013).

However, not all evaluative studies on RJC have come to such conclusions. The South Australian Juvenile Justice (SAJJ) study found 'limits' in the effectiveness of RJC in the level of mutual understanding between victims and offenders, and in the perceived sincerity of apologies for victims (Daly, 2002). Other research has found similar problems in terms of victim perceptions of youth offenders' apologies (Choi and Severson, 2009). Beyond problems related to the "restorativeness" ${ }^{\text {, }}$ and the perceived sincerity of apology of RJC for youth offenders, there is also ambiguity regarding its effectiveness on reoffending. The literature on $\mathrm{RJ}$ is mixed as to whether reducing reoffending should be seen as a primary goal of RJC (Robinson and Shapland, 2008). Nevertheless, such a goal has been set forth

\footnotetext{
${ }^{1}$ While scholars define the term restorativeness differently (Bazemore and Green, 2007), in this paper we follow the Daly's (2006: 141) definition as a level of 'mutual understanding' between victims and offenders because one of our intentions is to examine how limited developmental and cognitive capacities of youth offenders are linked to a low level of mutual understanding.
} 
cautiously by some RJC proponents (Walgrave, 2012) as well as cited as justification for the implementation and use of RJC programs (Gielen and Buccellato, 2010). To date, evidence from evaluative studies on reoffending is mixed, with some research finding a positive impact of RJC on reoffending (Sherman et al., 2015; Wong et al., 2016), and others finding minimal or no effects (Hayes, 2007; Livingstone et al., 2013; Weatherburn and Macadam, 2013).

Several scholars have suggested that problems with RJC in terms of restorativeness, sincerity of apology and reoffending may be attributed to limited capacity and immature characteristics of youth offenders (Daly, 2003; Haines, 2000; Hayes and Hayes, 2008; Lynch, 2010; Maruna et al., 2007; Newbury, 2011). A substantial body of literature demonstrates differences between youth and adult offenders in many developmental aspects (Cauffman and Steinberg, 2012; Richards, 2011; Scott and Steinberg, 2008b). To date, however, excepting research on the limited verbal ability of youth offenders (Hayes and Snow, 2013), there has been little examination of developmental, cognitive, or environmental impediments of youth offenders in terms of achieving restorative outcomes in RJC.

Scott and Steinberg (2008b) have argued it may be 'common sense' that youth offenders are different from adult offenders. Yet research from Gal (2011), who reanalysed data from the Reintegrative Shaming Experiment (RISE), found that younger victims had lower levels of satisfaction in RJC. They were often unable to fully express themselves in RJCs, and were more likely to experience long-lasting effects of crime than adult victims. Thus, while it may be common sense that youth offenders differ from adult ones in developmental or cognitive respects, there remains little recognition of these differences within research on the effectiveness and outcomes of RJC in relation to the age of offenders.

In this paper, we set forth a critical discussion of the suitability and appropriateness of RJC for youth offenders. We give an overview of the common rationales for RJC within youth justice before turning attention to what we see as limitations or problems regarding its 
appropriateness and potential effectiveness for young people. We focus specific attention on the impacts of limited developmental and cognitive capacities of youth offenders on the RJC process and outcomes, as these may effect young people most directly, but also victims of crime who may participate in RJCs. We conclude with recommendations as to how researchers and practitioners might better assess and address problems of suitability and appropriateness for young people in RJCs.

\section{The rationales for restorative justice conferencing with youth offenders}

At least three rationales are commonly provided as to why RJC is predominately used within youth justice. First, youth offenders generally commit less serious crimes than adult offenders (Dünkel and Pruin, 2012). RJC is thus often considered more appropriate for youth offenders due to the less serious nature of their offenses (Bruce et al., 2012; Richards, 2012), where such minor offenses may be better dealt with through less formal responses to offending (Johnstone, 2002); for example the replacing of police cautions with 'restorative cautions' in parts of the UK (Dignan, 2001), or the growing use of RJC as a type of diversionary practice

within Australia and New Zealand (Maxwell and Hayes, 2006). Existing research suggests that RJCs are utilised mainly for less serious offenses and/or youth offending in many countries (Zinsstag, 2012).

Second, youth offenders are considered less culpable than adult offenders (Steinberg and Scott, 2003). Relative to adults, youth offenders lack experiences in everyday life, and are generally less capable in using the ability to 'reason and to process information' to make informed decisions in real-world situations (Scott and Steinberg, 2008a: 20). Consequently, young people are more often likely to make impulsive decisions in relation to crime than adults (Cauffman et al., 2016). Considerations of such differences between youth and adult offenders has led to the establishment of separate youth justice systems in most countries (Dünkel and Pruin, 2012). Also, research has found that people tend to accept more lenient 
interventions for youth offenders than for adult offenders (Piquero and Steinberg, 2010). Restorative justice conferencing as a 'less punitive' option is thus often considered appropriate for youth offenders (Bazemore and Walgrave, 1999; Richards, 2012) as most types of juvenile crimes, particularly less serious ones, are considered an acceptable 'mistake' in the transition into adulthood (Bruce et al., 2012).

Finally, youth offenders are seen as less cognitively developed and emotionally mature than adults (Cauffman and Steinberg, 2012). As such, they are more malleable to environmental determinants, particularly family and peers (Steinberg and Schwartz, 2000). When youth behaviours are deemed 'inappropriate' in accordance with societal norms, childhood and adolescence are seen as the most opportune and effective place in the life course for approaches that seek to introduce more prosocial bonds (Hirschi, 1969), develop moral reasoning and empathy (Farrington and Welsh, 2007), and afford opportunities to correct past mistakes without significant prohibitions or enduing social stigma (Becker, 1963). Through moral communication that involves censure of delinquent behaviours and face-to-face dialogue with victims, RJC is seen as encouraging youth offenders to develop empathy and moral reasoning (Young and Hoyle, 2003), make amends to victims (Zehr, 1990), and through these to more successfully reintegrate into their communities (Braithwaite, 1989). As such, the compatibility of RJC with rehabilitative tradition of youth justice has attracted support from policy-makers and practitioners who seek pro-social and moral education for youth offenders (Bottoms, 2003; Newburn, 1998), in what Johnstone (2002: 137) has called the 'considerable movement towards a moralising and responsibilising response to young offenders without altogether abandoning welfarist concerns' of youth justice systems. 


\section{Effects of limited developmental and cognitive capacities of youth offenders on RJC}

Despite the rationales for utilising RJC for youth offenders, there are reasons to question the degree to which limited developmental and cognitive capacities may act as an impediment in achieving restorativeness, sincerity of apology, and reducing reoffending (Daly, 2003; Haines, 2000; Hayes and Hayes, 2008; Lynch, 2010; Maruna et al., 2007; Newbury, 2011). Below, we discuss how such 'limited' capacity and 'immature' characteristics may play an adverse role in RJC processes and outcomes.

\section{Limited comprehensibility and suggestibility}

Voluntary participation is widely seen as a prerequisite for participation of offenders in RJC (Boyack et al., 2004; Lynch, 2010). This works as a procedural safeguard where coerced participation may result in re-victimization (Vanfraechem et al., 2012) and lead to problems of resentment and the neutralization of harms for offenders (Hayden, 2014). Beyond serving as a procedural safeguard, voluntary participation may also play a role in achieving better restorative outcomes in RJCs (Suzuki and Wood, 2017a; Umbreit and Armour, 2010). In the SAJJ study, Daly (2005) found that about half of youth offenders showed interest in repairing harms caused to victims, while the other half were concerned more about their reputations. According to Daly (2005: 156), this potentially led to a lower level of mutual understanding between victims and offenders because of 'limits on offenders' interests to repair the harm'. Newbury (2011) interviewed youth offenders in the UK who participated in referral orders involving face-to-face dialogue with victims. Seven of the 31 youth offenders reported willingness to talk to and apologise to victims; the remaining 24 showed varying reluctance to meet victims, and 16 refused to apologise to victims (Newbury, 2011).

Equally problematic is that youth offenders may not understand 'voluntariness' of participation in RJC as willingness to engage with and make amends to victims. Research suggests that some youth offenders 'agree' to RJC largely out of self-interest, where the 
alternative is viewed as worse. Choi et al. (2010) interviewed youth offenders in the US to examine their motivations to participate in RJCs, finding that 'Although the offenders were able to think of their victims in describing their motivations, it seemed that the motivations were centred more on their own interests such as keeping "clean" records and moving forward' than addressing harms caused to victims (Choi et al., 2010: 864-865). This is consistent with research from Abrams et al. (2006: 253), who interviewed offenders aged 1524 that participated in RJCs in the US, concluding that some youth offenders participated primarily 'to look better in the eyes of the court'. Eskelinen and Iivari (2005: 129) surveyed 259 youth offenders about reasons they participated in RJCs in Finland, and found that about 30 percent of offenders did so because mediation corresponded 'to their own interest'.

Participation in RJC out of self-interest is not a problem unique to youth offenders. However, it may be more problematic for youth offenders than adult offenders as studies on RJC have found that youth offenders are not readily able to understand the difference between 'voluntary' and 'required' participation. Zernova's (2007a) interviews with 13 youth offenders who participated in RJC found that about a half thought their participation was compulsory, and that more than half participated out of fear of returning to court. Further research by Zernova (2007b) found that facilitators employed a variety of techniques, such as probing, to elicit youth offenders' consent to participate in RJC. Research in Ireland by Quigley et al. (2015) found that three out of nine youth offenders interviewed thought they had no choice but to participate in RJC because they were told so by their probation officer or out of fear of being returned to custody.

Studies such as these do not delineate a clear problem regarding coercion or lack of ability to understand voluntariness in RJC, nor have studies compared the levels of understanding on voluntariness between youth and adult offenders in RJC. However, research on other legal processes has also documented that young people may not understand their rights, 
obligations, and what is expected of them in legal or criminal justice settings or situations. Research in the US has found that youth below 15 tend to have a poor understanding of Miranda warnings and the rights attached to them (Grisso et al., 2003). The vulnerability of youth offenders in terms of suggestibility is also clear in research on police interrogations. According to Gudjonsson (2010), people become psychologically vulnerable during police interviews, regardless of their role - offender, victim, or witness - and sometimes provide information they think the police seek in order to cope with the pressure and stress of the interview. Young people are more vulnerable than adults in this respect (Richardson et al., 1995), as they are 'particularly susceptible to cues provided by adults and authority figures and their answers can be easily altered by pressure' (Gudjonsson and Singh, 1984: 429).

While Miranda Rights, police interrogations and voluntariness of participation in RJC are different concepts and situations, they share several characteristics. First, the rights and obligations attached to them appear difficult to grasp for many youth offenders. Also, they are all situations in which young offenders may have little power to resist pressure from authority. Third, they are also congruent in the exhibiting of authority and power backed up by threat or reality of punishment. Research by Dumortier (2003: 198) speaks to this last point in finding that 'Even certain minors who see themselves as being innocent are prepared to accept mediation in order to avoid any further legal procedure', and such fear of punishment may be 'motivational' enough for youth offenders to decide to participate in RJC following 'advice' from authority figures (Lynch, 2010).

\section{Insufficient communication skills}

Interaction between victims and offenders is one of the most important features of the RJC process (Hayes, 2006; Rossner, 2013). Through this interaction, restorative outcomes can emerge, for example, 'symbolic reparation' that can be more effective in repairing the harm caused by crime than even material reparation for victims to the degree that it may function to 
help restore a victim's dignity (Shapland et al., 2006). For symbolic reparation to occur, youth offenders need to express what is perceived by victims as genuine remorse, followed by victims' willingness to accept the apology and have the offender make amends (Retzinger and Scheff, 1996).

To achieve such bilateral effects, the RJC process requires sufficient verbal communication skills on the part of participants (Hayes and Snow, 2013). However, evidence suggests that youth offenders are frequently linguistically disadvantaged compared to adult offenders or even their non-delinquent peers (Hopkins et al., 2016; Snow and Powell, 2012). Bolitho's (2012) research on RJCs in New South Wales found about a half of youth offenders struggled to express themselves adequately in conferences. Stories were often brief and some offenders did not convey basic information related to offences or harms. Research in Northern Ireland similarly found that about half of youth offenders failed to engage in storytelling necessary for 'full account of the offence' due to their 'relative youth, nervousness, learning or behavioural difficulties, anger, defiance and/or lack of recall' (Beckett et al., 2005: 10).

Given the level of verbal skills required, the RJC process may thus be a 'second language environment' for youth offenders (Snow, 2013: 19). Lack of adequate verbal ability can be interpreted as 'undesirable behaviors, such as rudeness, disinterest, poor motivation, and lack of willingness to engage' (Snow, 2013:19), and limited verbal ability of youth offenders may lead to less restorative outcomes (Hayes and Snow, 2013; Maruna et al., 2007).

Communication in RJCs also involves more than verbal communication. Non-verbal messages from offenders such body language and posture, gestures, and eye contact are also important in terms of showing a commitment to dialogue with victims and willingness to repair the harm (Rossner, 2011). However, as with verbal communication, youth offenders also often lack appropriate non-verbal communication skills necessary for successful RJC 
outcomes. Campbell et al. (2006) observed 185 youth justice conferences in Northern Ireland and found that about 30 per cent of young people avoided eye contact 'a lot', and about 25 per cent 'a bit'. They also interviewed 125 victims and found that eye contact from offenders was important for many victims in terms of the perceived sincerity towards offenders, including apologies (Campbell et al., 2006). Based on case studies of RJCs in the US, Choi and Severson (2009: 819) found that the sincerity of youth offenders' apologies was questioned by victims when offenders failed to show 'non-verbal cues such as looking the victim in the eye, appearing to look remorseful in facial expressions, [or] speaking with a tone of respect'.

Research has similarly found that youth offenders may lack the ability to adequately express non-verbal messages. Sanger et al. (1999) observed conversations among 45 female delinquents in a correctional institution and then interviewed these women. While they were aware of the importance of eye contact, offenders were nevertheless unable to do so at appropriate times in conversation due to limited self-awareness and self-monitoring ability. To examine challenges in representing youth offenders in the legal process, Tobey et al. (2000) interviewed youth offenders and their lawyers, finding that youth offenders often failed to show attentive attitudes in formal legal settings due to boredom, emotional distress over the consequences, or lack understanding of the process (Tobey et al., 2000).

\section{Emotional immaturity}

Participants frequently feel or express a variety of negative emotions such as anger, fear or shame in RJCs (Harris et al., 2004; Rossner, 2013). Through face-to-face dialogue between victims and youth offenders, the RJC process is intended to transform these negative emotions into positive ones. Victims' stories may elicit positive emotions, such as remorse, in youth offenders. Youth offenders' stories or apologies may likewise provoke positive emotions, such as empathy, in victims (Hayes, 2006). 
It is not clear, however, whether most youth offenders are emotionally mature enough or able to follow such an emotional trajectory, particularly in regards to empathy (Wallis, 2014) and shame (Braithwaite, 1989), two emotions that are widely seen as core to successful RJC outcomes (Gamman and Thorpe, 2016; Kashyap, 2015). Empathy is the cognitive ability to understand the view point of others and share their feelings (Davis, 1983), and is important in RJC because youth offenders are expected to be able to listen to victims and understand the effects caused by their crimes (Harris et al., 2004). This interactive process in RJC, according to Wallis' (2014) empathy model, may help to develop empathy even among those who are not much empathetic toward the other party at the beginning of the process.

The development of empathy requires environmental conditions such as nurturing in childhood and opportunities to interact positively with others (Barnett, 1987). Yet many youth offenders come from disadvantaged backgrounds (Farrington et al., 2009; Thornberry, 2005), especially in terms of family relationships, where histories of parental neglect or abuse are frequently linked to delinquency (Farrington, 1993). In 'grown-up' environments such as RJC, young people are expected to display emotional maturity, even where many of them may have failed to 'proceed along path of healthy psychological development' (Scott and Steinberg, 2008b: 59) to nurture the ability to feel or express empathy. Several studies have indicated a link between youth offenders and lack of empathy (Hepper et al., 2014; Jolliffe and Farrington, 2007; Robinson et al., 2007).

The emotion of shame also plays important role in RJC (Masters, 1998). The theory of reintegrative shaming (Braithwaite, 1989) has been heavily integrated into RJC process and practice. According to this theory, shame may function in one of two ways - negatively where shame is internalized as part of the self-identity of the offender, or positively where shame is used to sanction a behaviour while affirming an offender's value as a person. This separation between wrongdoer and wrongdoing enables offenders to feel less threatened or 
stigmatized, ideally leading them to take responsibility for what they have done and motivating them to make amends and reintegrate into the communities (Braithwaite, 1989).

The role and effectiveness of shame in RJC has been contested, however (White, 1994). For youth offenders who have grown up environments 'guided by offending values and beliefs' (Toews and Katounas, 2004: 110), crime may not be seen as a violation of consensus of normative behaviours or values. Youth offenders may have different norms in relation to crime from others in society, leading them to being less shame-prone (Young and Hoyle, 2003) and more able to readily neutralize the harms caused to others (Sykes and Matza, 1957). These concerns about shame in RJC are evident in some existing studies. Vieira's (2003) research on youth offenders who participated in RJCs in Canada looked explicitly at the question of whether shame emerged as a result of RJC, and according to Vieira, shame was not emergent in most RJCs, but rather emotion of guilt. Based on studies of RJCs in New Zealand, Maxwell and Morris (2004) have also suggested that a shaming 'strategy' entails a risk of stigmatisation, leading to problems such as potential reoffending.

In the context of RJC, this vulnerability to shame in youth offenders may also emerge as a denial or mitigation of responsibility. In observing RJCs in Canada, Kenney and Clairmont (2008) found that some victims' harsh comments towards youth offenders led to neutralisation of harms. To mitigate their blameworthiness and make punishment less severe, youth claimed they also had suffered from the crime (Kenney and Clairmont, 2008). In reanalysis of the SAJJ and RISE studies, Hayes (2006) elaborated that neutralisation can also occur when youth offenders offer apologies. Hayes (2006: 378) notes that offenders' stories sometimes drifted 'from apologetic discourse to mitigating accounts and back again', and even where youth offenders offered apologies, these were less likely to be perceived as genuine or sincere by victims, but rather 'seen as attempts to acknowledge blame but deflect 
shame'. Similarly, research by Newbury (2011) showed that youth offenders in RJC felt difficulty in apologising due to fragile self-esteem.

\section{Power imbalance}

For RJCs to achieve restorative outcomes the process between victims, offenders and other parties needs to be inclusive and collaborative (Boyack et al., 2004). Participants should be able to freely express their thoughts, feelings, and accounting of events, and treated with respect by other parties as well as the facilitator. Such a process is vital in creating an environment that can help active engagement and moral communication (Boyack et al., 2004). Daly (2003) has further noted that establishing such processes are of particular importance for youth offenders since they are often easily intimidated.

Existing research suggests that the reality of RJC is often less sanguine where they may be an 'inherent' power imbalance between offenders and other participants, including facilitators (Umbreit, 2000; Young and Goold, 2003). This power imbalance becomes more problematic with youth offenders as they tend to have less 'power' than adults (Shapland, 2009), or what Haines (1998: 99) has called the situation of a 'room full of adults'. Such power imbalance can be exacerbated because of nervousness of youth offenders (Beckett et al., 2005; Campbell et al., 2006). Abrams et al. (2006) and Eskelinen and Iivari (2005) found that more than half of youth offenders felt nervous in terms of attending and expressing their opinions in RJC. In observations of conferences, Choi et al. (2011) similarly found that youth offenders frequently failed to express their emotions, such as remorse, due to their nervousness.

Power imbalance presents a risk that youth offenders may be coerced to accept what they are not willing to do, such as apologize or enter into an agreement (Haines, 2000; Lynch, 2010). Research by Beckett et al. (2005: 11) found that 25 percent of youth offenders agreed with the plan suggested in the RJC process because 'they "felt they had to".' Youth offenders 
are sometimes also pressured to offer apologies to victims. Hoyle et al. (2002) observed that in many cases in the police cautioning program in Thames Valley, facilitators attempted to elicit apologies from youth and adult offenders, even though offenders were not willing to do so.

Coerced apologies are particularly problematic in terms of RJCs. They are less likely to be perceived as sincere by victims because youth offenders appear to lack or convey genuine understanding of the impact of their crimes (Bennett, 2007). Furthermore, coerced apologies may negatively affect what Hayes and Hayes (2008) have called the 'ethical identity' of youth offenders, where such coercion functions to discourage offenders from critically and positively absorbing and reflecting on their experiences of RJC.

\section{Susceptibility to peer influence}

Thus far, our focus has been on questions related to how limited developmental and cognitive capacities for youth offenders may act as an impediment in achieving restorativeness and sincerity of apology in RJCs. However, over the past two decades, RJCs have increasingly been touted and implemented not only as a means of redress for victims, but as a viable and cost-effective intervention for reducing youth reoffending (Gielen and Buccellato, 2010).

However, research on the efficacy of RJCs to reduce reoffending is not conclusive, with some studies finding no effect (Hayes, 2007; Jeong et al., 2012; Weatherburn and Macadam, 2013), and others finding a small or moderate effect (Livingstone et al., 2013; Smith and Weatherburn, 2012). Notably, a recent systematic review of literature and meta-analysis of RJCs (Sherman et al., 2015: 13) concluded that in relation to reoffending:

Many public officials say that RJCs are more appropriate for juvenile offenders than for adults. Yet the findings from this Review suggest otherwise, at least for offenses with personal victims ... with the average effect of RJCs in six 
experiments with all adults is .150 standard deviations fewer future convictions than without RJCs ... [while] the average effect of RJCs on experiments with juveniles is only .119.

Given the strict criteria for inclusion of RJC studies in the review, Sherman et al. (2015) caution that other studies or types of RJ interventions may yield different results. Nevertheless, if Sherman et al. (2015) are correct that RJCs are more effective in reducing offending for adults than for juvenile offenders, it is less clear why.

One factor may be the types of offenses that adult and youth offenders were conferenced for in the studies included in Sherman et al.'s (2015) review. Youth with property or minor offenses scored worst on reoffending in general, while adults with violent offenses scored best in terms of reduced reoffending, leading the authors to conclude in their initial report that, 'If governments wish to fund Restorative Justice at all, this evidence suggests that the best return on investment will be with violent crimes, and also with offenders convicted after long prior histories of convictions' (Strang et al., 2013: 48).

Yet it is not clear from their review, and indeed in the larger research, if this difference is a matter of offense severity, age of offender, both, or other factors. Sherman et al. (2015: 19) do suggest 'RJCs may be a means by which authorities can foster "turning points" (Laub and Sampson, 2001; Sampson and Laub, 1991) in criminal careers'. This in turn leads to the question of whether they view RJCs as a possible 'turning point', or whether RJCs that occur within more well-established patterns of desistance in the life course, normally in early adulthood, are more likely to be effective than RJCs earlier in the life course of offenders. Drawing on Rossner's (2013) research on RJCs, Sherman et al. (2015: 20) suggest 'the more intensive and meaningful the quality of what Durkheim called "collective effervescence" in a highly emotional discussion of the harm a crime had caused to someone in the room, the bigger the effect seems to be on reducing recidivism'. This bring us back to the problems we 
have discussed above in terms of ways that youth offenders may fail to emotionally engage in the RJC process.

However, even if youth offenders are able to successfully engage in RJC, it is still not clear such engagement may in turn positively affect reoffending. Since RJC is a 'one-off' and 'time-limited' intervention (Hayes, 2007), it is not an intervention focused on addressing underlying socio-economic (Lofton, 2004) or behavioural correlates of offending (Maxwell and Morris, 1994). This is in part why there remains debate about whether reducing future offending should be a reasonable goal of RJC (Robinson and Shapland, 2008). Maxwell (2008: 93) has argued that RJC may be 'only one of many factors' that influence youth offenders' lives, and many offenders who participate in RJC still have various risk factors, such as drug and alcohol problems, behavioural problems, lack of family structure and support, lack of education, poor employment opportunities, and so on (Corrado et al., 2003; Suzuki and Wood, 2017b).

One risk factor relevant to characteristics of youth offenders in terms of the life course is delinquent peers. Research suggests that young people are more susceptible to peer influence that adults (Cauffman and Steinberg, 2012; Richards, 2011; Scott and Steinberg, 2008b). Research by Steinberg and Monahan (2007) found that younger people are more vulnerable to peer influence between the ages of 14 and 18, which given the predominant use of RJC with youth offenders, corresponds closely to the ages of most young people who go through the RJC process. Fagan (2000: 384) has suggested that the decision to engage in crime is affected by not only by personality factors but by the 'internalized norms of neighborhood'. The more often young people hang around delinquent friends, the more likely they may be to be involved in antisocial activities (Megens and Weerman, 2012; Seddig, 2014). Since most youth offenders go back into the same community after RJC (Liebmann, 2007), some of them 
may engage in further delinquency under peer influence, even where they may have a positive experience in RJC.

To our knowledge, there has been no research on the question of how RJCs may overlap with the sizable research on life-course and developmental criminology in terms of why RJCs may have more of an impact on reoffending for types of offenses and/or age and offending history. We do know that susceptibility to peer influence wanes as many offenders move into adulthood (Cauffman and Steinberg, 2012; Steinberg and Monahan, 2007). Research also suggests that empathy increases as young people move into adulthood (Lee and Prentice, 1988; O'Brien et al., 2013). As RJCs are predicted, in part, on the eliciting of empathy from offenders, and where research has demonstrated differences between offending and nonoffending youth in the demonstration of empathetic concern for others (Eisenberg and Fabes, 1998; Kaplan and Arbuthnot, 1985), it may be that the impact on younger offenders in terms of reoffending is less demonstrable not because of offense type or offending history but because of the point in the life course where RJCs are used. Clearly there is a need for such research, which would help not only to better understand if and why adult offenders may respond more positively to RJCs than youth offenders in terms of reoffending, but also whether such a goal for the use of RJCs with youth offenders is a realistic one.

\section{Concluding remarks}

In the beginning of this paper, we set forth three of the most common justifications used in RJ literature and practices for the use of RJCs with youth offenders. As we have detailed in our arguments above, however, there are notable problems with all of these assumptions as they relate to existing research on RJC, as well as in criminological and other literatures on young people and youth offending. 
Notably, it is not clear from existing research that the seriousness of the offense or offending history is a good indicator of successful RJC outcomes. Indeed, some existing research seems to suggest that RJCs may in fact work better for adult offenders and/or more serious offenses. This alone does not imply that RJCs are not appropriate for younger offenders and/or less serious offenses. Yet while the importance of focusing on limited capacity and immature characteristics of youth offenders in order to address youth crime is highlighted in a wealth of psychological and criminological literature (Cauffman and Steinberg, 2012; Richards, 2011; Scott and Steinberg, 2008b), little attention has been paid to these in the RJC context. In this paper, we have given attention to problems specifically related to youth offenders that can have adverse effects on youth RJC processes and outcomes: limited comprehensibility and suggestibility, insufficient communication skills, emotional immaturity, power imbalance, and susceptibility to peer influence.

Several studies we have cited above link one or more of the problems we have discussed to poor restorative processes or outcomes. This leads us to question the presumed suitability or appropriateness of RJC for youth offenders. Where most screening processes seek to identify youth offenders that may not be suitable for RJC, such screening is generally geared towards identifying whether youth offenders are willing to accept responsibility for their actions, and whether they present a risk of re-victimizing the victim (Vanfraechem et al., 2012).

However, there is a paucity of discussion or research on how to facilitate the RJC process in relation to the problems we have discussed above. Towards addressing these problems, we suggest it may be beneficial to develop facilitation guidelines based on youth capacity and characteristics. Indeed, while a significant focus has been on face-to-face dialogue in the process, less attention has been paid to screening and preparatory phases. Given the problems derived from youth capacity and characteristics discussed above, more rigorous eligibility 
criteria may be necessary for youth offenders. This may include establishing eligibility criteria that include not only 'common' checklists currently used, such as acknowledgement of guilt and seriousness of offence, but whether youth offenders are cognitively and developmentally mature enough in terms of comprehensibility, emotionality and communication capacity. In addition, development of specific preparatory strategies for youth offenders may go some way towards identifying and redressing such problems, when possible. For instance, practitioners need to identify what specific skills or abilities youth offenders lack, such as verbal ability, and address these issues during preparation (Hayes and Snow, 2013).

To date, there are no comparative studies on the effects of RJC between youth and adult offenders. Although the effects of youth capacity and characteristics in RJC discussed above have been partly supported by extant empirical RJC literature, without directly comparing youth and adult offenders, they remain speculative, and such research is needed. Another possibility is to examine the effects of youth capacity and characteristics in the 'variability' of RJC (Hayes and Daly, 2003) within youth offenders. People experience trajectories into maturity at different speeds. Even if age is same, youth offenders have different level of capacity and maturity. By comparing RJC process and outcome between youth offenders who are relatively more and less mature, we can better ascertain and identify the effects of youth capacities and characteristics as they relate to restorative processes and outcomes. 


\section{References}

Abrams LS, Umbreit M and Gordon A. (2006) Young offenders speak about meeting their victims: Implications for future programs. Contemporary Justice Review 9(3): $243-$ 256.

Barnett MA. (1987) Empathy and related responses in children. In Eisenberg N and Strayer J (eds) Empathy and its Development. New York, NY: Cambridge University Press, $142-162$.

Bazemore G and Green DL. (2007) "Yardsticks" for victim sensitive process: Principle-based standards for gauging the integrity of restorative justice process. Victims \& Offenders 2(3): 289-301.

Bazemore G and Walgrave L. (1999) Restorative juvenile justice: In search of fundamentals and an outline for systemic reform. In Bazemore $\mathrm{G}$ and Walgrave $\mathrm{L}$ (eds) Restorative juvenile justice: Repairing the harm of youth crime. Monsey, NY: Criminal Justice Press, 45-74.

Becker HS. (1963) Outsiders: Studies in the sociology of deviance, New York, NY: The Free Press.

Beckett H, Campbell C, O'Mahoney D, et al. (2005) Interim evaluation of the Northern Ireland youth conferencing scheme. Belfast: Northern Ireland Office.

Bennett C. (2007) Satisfying the needs of interests of victims. In Johnstone G and Van Ness DW (eds) Handbook of restorative justice. Devon: Willan Publishing, 247-264.

Bolitho JJ. (2012) Restorative justice: The ideals and realities of conferencing for young people. Critical Criminology 20(1): 61-78.

Bottoms A. (2003) Some sociological reflections on restorative justice. In von Hirsch A, Roberts J, Bottoms AE, et al. (eds) Restorative justice and criminal justice: Competing or reconcilable paradigms? Portland, OR: Hart Publishing, 79-114. 
Boyack J, Bowen H and Marshall C. (2004) How does restorative justice ensure good practice? In Zehr $\mathrm{H}$ and Toews B (eds) Critical issues in restorative justice. Boulder, CO: Criminal Justice Press, 265-276.

Braithwaite J. (1989) Crime, shame and reintegration, Cambridge, UK: Cambridge University Press.

Bruce J, Mason G and Bolitho J. (2012) Restorative justice: From juvenils to adults. In Bolitho J, Bruce J and Mason G (eds) Restorative justice: Adults and emerging practice. Sydney: The Federation Press, 1-16.

Campbell C, Devlin R, O'Mahony D, et al. (2006) Evaluation of the Northern Ireland youth conference service. Belfast: Northern Ireland Office.

Cauffman E, Cavanagh C, Donley S, et al. (2016) A developmental perspective on adolescent risk-taking and criminal behavior. In: Piquero AR (ed) The Handbook of Criminological Theory. Surrey: Wiley-Blackwell, 100-120.

Cauffman E and Steinberg L. (2012) Emerging findings from research on adolescent development and juvenile justice. Victims \& Offenders 7(4): 428-449.

Choi JJ, Green DL and Gilbert MJ. (2011) Putting a human face on crimes: A qualitative study on restorative justice processes for youths. Child and Adolescent Social Work 28(5): 335-355.

Choi JJ, Green DL and Kapp SA. (2010) A qualitative study of victim offender mediation: Implications for social work. Journal of Human Behavior in the Social Environment 20(7): 857-874.

Choi JJ and Severson M. (2009) "What! What kind of apology is this?": The nature of apology in victim offender mediation. Children and Youth Services Review 31(7): 813-820. 
Corrado RR, Cohen IM and Odgers C. (2003) Multi-problem violent youth: A challenge for the restorative justice paradigm. In Weitekamp EGM and Kerner HJ (eds) Restorative justice in context: International practice and directions. Devon: Willan Publishing, 122.

Dünkel F and Pruin I. (2012) Young adult offenders in juvenile and criminal justice systems in europe. In Lösel F, Bottoms A and Farrington DP (eds) Young adult offenders: Lost in transition? London: Routledge, 11-38.

Daly K. (2002) Restorative justice: The real story. Punishment \& Society 4(1): 55-79.

Daly K. (2003) Mind the gap: Restorative justice in theory and practice. In von Hirsch A, Roberts J, Bottoms AE, et al. (eds) Restorative justice and criminal justice: Competing or reconcilable paradigms? Portland, OR: Hart Publishing, 219-237.

Daly K. (2005) A tale of two studies: Restorative justice from a victim’s perspective. In Elliott E and Gordon RM (eds) New directions in restorative justice: Issues, practice, evaluation. Devon: Willan Publishing, 152-174.

Daly K. (2006) The limits of restorative justice. In Sullivan D and Tifft L (eds) Handbook of restorative justice: A global perspective. Oxon: Routledge, 134-146.

Davis MH. (1983) Measuring individual differences in empathy: Evidence for a multidimensional approach. Journal of Personality and Social Psychology 44(1): 113126.

Dignan J. (2001) Restorative justice and crime reduction: Are policy-makers barking up the wrong tree? In Fattah E and Parmentier S (eds) Victim policies and criminal justice on the road to restorative justice. Leuven: Leuven University Press, 329-352.

Dumortier E. (2003) Legal rules and safegaurds within belgian mediation practices for juveniles. In Weitekamp EGM and Kerner H-J (eds) Restorative justice in context: International practice and directions. Devon: Willan Publishing, 197-207. 
Eisenberg N and Fabes RA. (1998) Prosocial development. In Damon W and Lerner RL (eds) Handbook on child psychology. New York, NY: John Wiley \& Sons, Inc., 701-778.

Eskelinen O and Iivari J. (2005) Victim-offender medaition with juvenile offenders in Finland. In Mestitz A and Ghetti S (eds) Victim-offender mediation with youth offenders in Europe: An overview and comparison of 15 countries. Dordrecht: Springer, 115-136.

Fagan J. (2000) Contexts of choice by adolescents in criminal events. In Grisso T and Schwartz RG (eds) Youth on trial: A developmental perspective on juvenile justice. Chicago, IL: The University of Chicago Press, 371-402.

Farrington DP. (1993) Childhood origins of teenage antisocial behaviour and adult social dysfunction. JRSM 86(1): 13-17.

Farrington DP, Coid JW and Murray J. (2009) Family factors in the intergenerational transmission of offending. Criminal Behaviour and Mental Health 19(2): 109-124.

Farrington DP and Welsh BC. (2007) Saving children from a life of crime: Early risk factors and effective interventions. Studies in crime and public policy, New York, NY: Oxford University Press.

Gal Ta. (2011) Child victims and restorative justice: A needs-rights model, New York, NY: Oxford University Press.

Gamman L and Thorpe A. (2016) "Design for empathy" - exploring the potential of participatory design for fostering restorative values and contributing to restorative process. In Gavrielides T (ed) Offenders no more: An interdisciplinary restorative justice dialogue. New York, NY: Nova Science Publishers, 79-100.

Gielen A and Buccellato N. (2010) Restorative justice and crime prevention policies in the EUu member states. In Italian Department of Juvenile Justice (ed) Restorative justice 
and crime prevention: Presenting a theoretical exploration, an empirical analysis and the policy perspective. Rome: Italian Department of Juvenile Justice, 82-155.

Grisso T, Steinberg L, Woolard J, et al. (2003) Juveniles' competence to stand trial: A comparison of adolescents' and adults' capacities as trial defendants. Law and Human Behavior 27(4): 333-363.

Gudjonsson GH. (2010) Psychological vulnerabilities during police interviews. Why are they important? Legal and Criminological Psychology 15(2): 161-175.

Gudjonsson GH and Singh KK. (1984) Interrogative suggestibility and delinquent boys: An empirical validation study. Personality and Individual Differences 5(4): 425-430.

Haines K. (1998) Some principled objections to a restorative justice approach to working with juvenile offenders. In Walgrave L (ed) Restorative justice for juveniles: Potentialities, risks and problems for research. Leuven: Leuven University Press, 93114.

Haines K. (2000) Referral orders and youth offender panels: Restorative approaches and the new youth justice. In Goldson B (ed) The new youth justice. Dorset: Russell House Publishing, 58-80.

Harris N, Walgrave L and Braithwaite J. (2004) Emotional dynamics in restorative conferences. Theoretical Criminology 8(2): 191-210.

Hayden A. (2014) Perpetrator's and victims' view of restorative justice and intimate partner violence. In Hayden A, Gelsthorpe L, Kingi V, et al. (eds) A restorative approach to family violence: Changing track. Surrey: Ashgate, 159-168.

Hayes H. (2006) Apologies and accounts in youth justice conferencing: Reinterpreting research outcomes. Contemporary Justice Review 9(4): 369-385.

Hayes H. (2007) Reoffending and restorative justice. In Johnstone G and Van Ness DW (eds) Handbook of restorative justice. Devon: Willan Publishing, 426-444. 
Hayes H and Daly K. (2003) Youth justice conferencing and reoffending. Justice Quarterly 20(4): $725-764$.

Hayes H and Snow P. (2013) Oral language competence and restorative justice processes: Refining participation and the measurement of conference outcomes. Trends and Issues in Crime and Criminal Justice 463: 1-7.

Hayes S and Hayes H. (2008) Developing ethical identities in young offenders through restorative justice practice in Australia. Queensland University of Technology Law \& Justice Journal 8(2): 380-391.

Hepper EG, Hart CM, Meek R, et al. (2014) Narcissism and empathy in young offenders and no-offenders. European Journal of Personality 28(2): 201-210.

Hirschi T. (1969) Causes of delinquency, Berkeley, CA: University of California Press.

Hopkins T, Clegg J and Stackhouse J. (2016) Young offenders' perspectives on their literacy and communication skills. International Journal of Language \& Communication Disorders 51(1): 95-109.

Hoyle C, Young R and Hill R. (2002) Proceed with caution: An evaluation of the Thames Vally police initiative in restorative cautioning. York: Joseph Rowntree Foundation.

Jeong S, McGarrell EF and Hipple NK. (2012) Long-term impact of family group conferences on re-offending: The indianapolis restorative justice experiment. Journal of Experimental Criminology 8(4): 369-385.

Johnstone G. (2002) Restorative justice: Ideas, values, debates, Oxon: Routledge.

Jolliffe D and Farrington DP. (2007) Examining the relationship between low empathy and self-reported offending. Legal and Criminological Psychology 12(2): 265-286.

Kaplan P and Arbuthnot J. (1985) Affective empathy and cognitive role-taking in delinquent and non-delinquent youth. Adolescence 20(78): 323-333. 
Kashyap R. (2015) The concept of humiliation as a critical issue in restorative justice: An exploration. In Gavrielides T (ed) The psychology of restorative justice: Managing the power within. Surrey: Ashgate, 121-138.

Kenney JS and Clairmont D. (2008) Using the victim role as both sword and shield: The interactional dynamics of restorative justice sessions. Journal of Contemporary Ethnography 38(3): 279-307.

Laub JH and Sampson RJ. (2001) Understanding desistance from crime. Crime and Justice 28: 1-69.

Lee M and Prentice NM. (1988) Interrelations of empathy, cognition, and moral reasoning with dimensions of juvenile delinquency. Journal of Abnormal Child Psychology 16(2): 127-139.

Liebmann M. (2007) Restorative justice: How it works, Philadelphia, PA: Jessica Kingsley Publishers.

Livingstone N, Macdonald G and Carr N. (2013) Restorative justice conferencing for reducing recidivism in young offenders (aged 7 to 21). Cochrane Dataase of Systematic Reviews. Cochrane Collaboration.

Lofton BP. (2004) Does restorative justice challenge systemic injustices? In Zehr H and Toews B (eds) Critical issues in restorative justice. Boulder, CO: Criminal Justice Press, 381-390.

Lynch N. (2010) Restorative justice through a children's rights lens. The International Journal of Children's Rights 18: 161-183.

Maruna S, Wright S, Brown J, et al. (2007) Youth conferencing as shame managemet: Results of a long-term follow-up study. Cambridge: ARCS. 
Masters G. (1998) The importance of shame to restorative justice. In Walgrave L (ed) Restorative justice for juveniles: Potentialities, risks and problems for research. Leuven, Belgium: Leuven University Press, 123-136.

Maxwell G. (2008) Crossing cultural boundaries: Implementing restorative justice in international and indigenous contexts. In Miller HV (ed) Restorative justice: From theory to practice. Bingley: Emerald Group Publishing, 81-95.

Maxwell G and Hayes H. (2006) Restorative justice developments in the Pacific region: A comprehensive survey. Contemporary Justice Review 9(2): 127-154.

Maxwell G and Morris A. (1994) The new zealand model of family group conferences. In Alder C and Wundersitz $\mathrm{J}$ (eds) Family conferencing and juvenile justice: The way forward or misplaced optimism? Canberra: Austrailan Institute of Criminology, 1443.

Maxwell G and Morris A. (2004) What is the place of shame in restorative justice? In Zehr H and Toews B (eds) Critical issues in restorative justice. Boulder, CO: Criminal Justice Press, 133-142.

Megens KCIM and Weerman FM. (2012) The social transmission of delinquency: Effects of peer attitudes and behavior revisited. Journal of Research in Crime and Delinquency 49(3): 420-443.

Newburn T. (1998) Tackling youth grime and reforming youth justice: The origins and nature of 'new labour' policy. Policy Studies 19(3-4): 199-212.

Newbury A. (2011) 'I would have been able to hear what they think': Tensions in achieving restorative outcomes in the English youth justice system. Youth Justice 11(3): 250265. 
O'Brien E, Konrath SH, Grühn D, et al. (2013) Empathic concern and perspective taking: Linear and quadratic effects of age across the adult life span. Journals of Gerontology 68(2): 168-175.

Piquero AR and Steinberg L. (2010) Public preferences for rehabilitation versus incarceration of juvenile offenders. Journal of Criminal Justice 38(1): 1-6.

Quigley M, Martynowicz A and Gardner C. (2015) Building bridges: An evaluation and social return on investment study of the le chéile restorative justice project. Le Chéile: Le Chelie Mentoring and Youth Justice Support Services.

Retzinger SM and Scheff TJ. (1996) Strategy for community conferences: Emotions and social bonds. In Galaway B and Hudson J (eds) Restorative justice: International perspectives. Monsey, NY: Criminal Justice Press, 315-336.

Richards K. (2011) What makes juvenile offenders different from adult offenders? Trend \& Issues in Crime and Criminal Justice 409: 1-8.

Richards K. (2012) Restorative justice for victims of adult crime: An exploration of theory and evidence. In Bolitho J, Bruce J and Mason G (eds) Restorative justice: Adults and emerging practice. Sydney: The Federation Press, 142-155.

Richardson G, Gudjonsson GH and Kelly TP. (1995) Interrogative suggestibility in an adolescent forensic population. Journal of Adolescence 18(2): 211-216.

Robinson G and Shapland J. (2008) Reducing recidivism: A task for restorative justice? British Journal of Criminology 48(3): 337-358.

Robinson R, Roberts WL, Strayer J, et al. (2007) Empathy and emotional responsiveness in delinquent and non-delinquent adolescents. Social Development 16(3): 555-579.

Rossner M. (2011) Emotions and interaction ritual: A micro analysis of restorative justice. British Journal of Criminology 51(1): 95-119. 
Rossner M. (2013) Just emotions: Rituals of restorative justice, Oxford: Oxford University Press.

Sampson RJ and Laub JH. (1991) Crime in the making: Pathways and turning points through life, Cambridge, MA: Harvard University Press.

Sanger DD, Hux K and Ritzman M. (1999) Female juvenile delinquents' pragmatic awareness of conversational interactions. Journal of Communication Disorders 32(5): 281-295.

Scott ES and Steinberg L. (2008a) Adolescent development and the regulation of youth crime. The Future of Children 18(2): 15-33.

Scott ES and Steinberg LD. (2008b) Rethinking juvenile justice, Cambridge, MA: Harvard University Press.

Seddig D. (2014) Peer group association, the acceptance of norms and violent behaviour: A longitudinal analysis of reciprocal effects. European Journal of Criminology 11(3): 319-339.

Shapland J. (2009) Restorative justice conferencing in the context of community policing. In Moor LG, Peters T, Ponsaers P, et al. (eds) Restorative policing. Antwerp: Cahiers Politiestudies, 119-138.

Shapland J, Atkinson A, Atkinson H, et al. (2006) Situating restorative justice within criminal justice. Theoretical Criminology 10: 505-532.

Sherman LW, Strang H, Mayo-Wilson E, et al. (2015) Are restorative justice conferences effective in reducing repeat offending? Findings from a campbell systematic review. Journal of Quantitative Criminology 31(1): 1-24.

Smith N and Weatherburn D. (2012) Youth justice conferences versus children's court: A comparison of re-offending. Contemporary Issues in Crime and Justice 160: 1-23. 
Snow P. (2013) Restorative justice conferencing, oral language competence, and young offenders: Are these high-risk conversations? Prevention Researcher 20(1): 18-20.

Snow P and Powell M. (2012) Youth (in)justice: Oral language competence in early life and risk for engagement in antisocial behaviour in adolescence. Trend \& Issues in Crime and Criminal Justice (Generic): 1-6.

Steinberg L and Monahan KC. (2007) Age differences in resistance to peer influence. Developmental psychology 43(6): 1531-1543.

Steinberg L and Schwartz RG. (2000) Developmental psychology goes to court. In Grisso T and Schwartz RG (eds) Youth on trial: A developmental perspective on juvenile justice. Chicago, IL: The University of Chicago Press, 9-32.

Steinberg L and Scott ES. (2003) Less guilty by reason of adolescence: Developmental immaturity, diminished responsibility, and the juvenile death penalty. American Psychologist 58(12): 1009-1018.

Strang H, Sherman LW, Mayo-Wilson E, et al. (2013) Restorative justice conferencing (RJC) using face-to-face meetings of offenders and victims: Effects on offender recidivism and victim satisfaction. A systematic review. Oslo: The Campbell Collaboration.

Suzuki M and Wood WR. (2017a) Co-option, coercion and compromise: Challenges of restorative justice in victoria, australia. Contemporary Justice Review.

Suzuki M and Wood WR. (2017b) Restorative justice conferencign as a 'holistic' process: Convenor perspectives. Current Issues in Criminal Justice 28(3): 277-292.

Sykes GM and Matza D. (1957) Techniques of neutralization: A theory of delinquency. American Sociological Review 22(6): 664-670.

Thornberry TP. (2005) Explaining multiple patterns of offending across the life course and across generations. The ANNALS of the American Academy of Political and Social Science 602(1): 156-195. 
Tobey A, Grisso T and Schwartz R. (2000) Youths' trial participation as seen by youths and their attorneys: An exploration of competence-based issues. In Grisso T and Schwartz RG (eds) Youth on trial: A developmental perspective on juvenile justice. Chicago, IL: The University of Chicago Press, 225-242.

Toews B and Katounas J. (2004) Have offenders needs and perspectives been adequately incorporated into restorative justice? In Zehr H and Toews B (eds) Critical issues in restorative justice. Boulder, CO: Criminal Justice Press, 107-118.

Umbreit MS. (2000) Family group conferencing: Implications for crime victims. Washington, D. C.: U.S. Department of Justice Office of Justice Programs.

Umbreit MS and Armour MP. (2010) Restorative justice dialogues: An essential guide for research and practice, New York, NY: Springer Publishing Company.

Vanfraechem I, Lauwaert K and Decocq M. (2012) Conferencing at the crossroards between rehabilitation and restorative justice. In Zinsstag E and Vangraechem I (eds) Conferencing and restorative justice: International practices and perspectives. Oxford: Oxford University Press, 189-204.

Vieira TA. (2003) Emotions and young offenders' suitability for victim-offender mediation. the 111th Annual Conference of the American Psychological Association. Toronto, Canada.

Walgrave L. (2012) The need for clarity about restorative justice conferences. In Zinsstag E and Vangraechem I (eds) Conferencing and restorative justice: International practices and perspectives. Oxford: Oxford University Press, 33-46.

Wallis P. (2014) Understanding restorative justice: How empathy can close the gap created by crime, Bristol: Policy Press.

Weatherburn D and Macadam M. (2013) A review of restorative justice responses to offending. Evidence Base 1: 1-20. 
White R. (1994) Shame and reintegration strategies: Individuals, state power and social interests. In Alder $\mathrm{C}$ and Wundersitz $\mathrm{J}$ (eds) Family conferencing in wagga wagga: A communitarian model of justice. Canberra: Austrailan Institute of Criminology, 181196.

Wong JS, Bouchard J, Gravel J, et al. (2016) Can at-risk youth be diverted from crime?: A meta-analysis of restorative diversion programs. Criminal Justice and Behavior 43(10): 1310-1329.

Young R and Goold B. (2003) Restorative police cautioning in aylesbury - from degrading to reintegrative shaming ceremonies. In McLaughlin E, Fergusson R, Hughes G, et al. (eds) Restorative justice: Critical issues. London: Sage Publications, 94-104.

Young R and Hoyle C. (2003) Restorative justice and punishment. In McConville S (ed) The use of punishment. Devon: Willan Publishing, 199-234.

Zehr H. (1990) Changing lenses: A new focus for crime and justice, Scottdale, PA: Herald Press.

Zernova M. (2007a) Aspirations of restorative justice proponents and experiences of participants in family group conferences. British Journal of Criminology 47(3): 491509.

Zernova M. (2007b) Restorative justice: Ideals and realities, Aldershot: Ashgate Publishing. Zinsstag E. (2012) Conferencing: A developing practice of restorative justice. In Zinsstag E and Vangraechem I (eds) Conferencing and restorative justice: International practices and perspectives. Oxford: Oxford University Press, 11-32. 